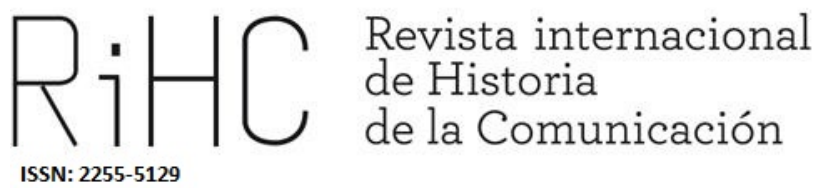

\title{
LA FOTOGRAFÍA DE MODA Y EL SURREALISMO FOTOGRÁFICO. UNA RELACIÓN SIN FIN
}

\section{Fashion photography and surreal photography. A never ending relationship}

DOI: http://dx.doi.org/10.12795/RiHC.2018.i10.05

Recibido: 08/03/2018

Aceptado: $25 / 04 / 2018$

Publicado: $25 / 05 / 2018$

Beatriz Guerrero González-Valerio (iD) https://orcid.org/0000-0002-7552-9553

Universidad CEU-San Pablo, beguergo@ceu.es

Cristina Barreiro Gordillo (D) https://orcid.org/0000-0002-0121-9771

Universidad CEU-San Pablo, cbarreiro@ceu.es

Resumen: Este artículo propone un estudio de la fotografía de moda como cruce entre el elemento comercial y el arte, y dónde la influencia de la corriente surrealista se presenta continua. El análisis de algunos fotógrafos de moda que se inspiran en el surrealismo, y una interpretación de éste a nivel fotográfico nos lleva -siguiendo una estructura deductiva- a demostrar la idea del encuentro entre lo mercantil y el arte surrealista. Ejemplos tempranos de fotógrafos de moda que apuestan por el surrealismo los encontramos en el polifacético Man Ray, introductor de la 
experimentación en la fotografía de moda, en los años 40 en Erwin Blumenfeld, y ya en los años 70 destacó el francés Guy Bourdin.

Palabras clave: fotografía de moda, arte, surrealismo fotográfico.

Abstract: This article, following a deductive structure, aims to demonstrate how fashion photography, despite belonging to the fashion industry, is a crossover between the commercial aspect and art, moreover, the influence of the surrealistic aspect has had a continuous trend. The analysis of some fashion photographers inspired by surrealism and the thorough study of surrealism from a photographic stand point will give us the opportunity to demonstrate the idea of the encounter between mercantilism and surrealistic art. Some examples of photographers that introduced surrealism can be quoted, Man Ray as an example of early surrealism introduced experimenting in fashion photography, in the 40's we can distinguish Erwin Blumenfeld, and later on, in the 70's French photographer, Guy Bourdin stands out.

Keywords: fashion photography, art, photographic surrealism

\section{Metodología}

La relevancia del surrealismo fotográfico en la década inmediatamente posterior a 1918, ha sido sobradamente trabajada e investigada por autores como Petr Tausk (1978). En este sentido, se echaba en falta un estudio que se adentrase en la pervivencia de esta influencia artística, pasado el calor de su mayor esplendor en la Europa de entreguerras, para acercarse a tiempos posteriores que cubriesen la última mitad del siglo XX. Por ello, este artículo pretende avanzar en el análisis de la influencia de las corrientes surrealistas en la fotografía de moda comprendido entre 1930 y 1970 , periodo menos abordado por la historiografía. Para su elaboración hemos recurrido a una metodología descriptiva en la que los componentes deductivos nos llevan a la confirmación de la tesis planteada. En este sentido, y partiendo de una bibliografía de análisis general con trabajos como los de José Manuel Susperregui (2000), Marie Loup Sougez (2011) o Beaumont Newhall (2002) y los estudios en el campo de la fotografía de moda de la profesora Casajús (1993), que se convierten en punto de partida para establecer un marco conceptual de referencia, nos adentrarnos en el mundo del arte y el surrealismo de la mano de Francois Baudot (2003) en una transversalidad que reafirma la hipótesis inicial. Por ello, para ser capaces de demostrar el cruce entre el elemento comercial, el arte y la influencia de la corriente surrealista en el campo de la fotografía de la moda posterior a 1930, se ha decidido concretar el análisis en Erwin Blumenfeld y Guy Bourdin. Para esta selección, se ha optado por acotar el campo de trabajo con el objeto de reflejar la evolución de las interrelaciones descritas, en la etapa seleccionada: de una inicial búsqueda de la renovación fotográfica en el periodo de entreguerras -profundamente marcado por las líneas europeas experimentales de 
los años 20 y 30- en el artista alemán afincado tras 1941 en Estados Unidos, hasta la irrupción en los años 60-70 del pret- à- porter siempre afectado por las artes de la vanguardia surrealista, en la figura del creador francés. Han quedado fuera del estudio, creadores como Man Ray, quién pese a su apuesta por el surrealismo en la experimentación de la fotografía de moda, antecede el marco temporal escogido para el análisis. El mismo argumento se ha considerado válido para el fotógrafo inglés Tim Walker, si bien en este caso su obra responde esencialmente a criterios contemporáneos. Por todo ello, el haber acotado los parámetros temporales del trabajo fotográfico de los artistas presentados a las décadas 30/70, nos ha permitido certificar cómo el surrealismo en su aspecto expresivo, se ha convertido en fuente de inspiración para los fotógrafos estudiados más allá del final de la Primera Guerra Mundial, periodo consagrado como máximo exponente del surrealismo fotográfico y sobre el que existían trabajos de renombrada calidad científica.

\section{La fotografía de moda}

La fotografía va más allá de ser un mero medio técnico: es también un medio de comunicación y de expresión. Así mismo, tiene usos muy diversos encontrándose entre sus aplicaciones la fotografía de moda. Moda y la fotografía son dos disciplinas que van de la mano porque ambas son fundamentalmente visuales, pese al importante componente físico -hecha para ser vestida- que encontramos en la primera. Podría definirse la fotografía de moda como una imagen conceptual que posee, además, gran calidad, belleza y que responde, generalmente, a importante maestría técnica. Sin embargo, la fotografía de moda, además de crear imágenes en las que impera la estética, crea imágenes que juegan con las aspiraciones, los deseos y anhelos del público. Para ello, se intentan provocar emociones, se aplica la fantasía, el misterio y también, a menudo, el humor.

La fotografía de moda ha mostrado a todos, y no a una minoría, cosas que estaban ocultas, algunas las vio ella primero, otras se las proporcionó la fotografía y la pintura. Además, ha servido para desarrollar la visión del espectador, para que él pueda descubrir nuevas formas de percepción. (Casajús, 1993: 352)

La moda significa esencialmente cambio, entendido como una sucesión de tendencias y de novedades a corto plazo. Hablar de moda es hablar de constante transformación, así lo expresa Josefina Figueras, "moda lleva implícita una serie de condiciones básicas: sentido de la fugacidad, interés por el cambio, variaciones de la apariencia, amor incondicional para todo lo que signifique novedad" (Figueras, 1997: 13). Partiendo de esta idea puede haber muchos tipos de modas, de hecho, infinidad de actividades 
humanas pueden estar sujetas a modas. Sin embargo, el concepto de moda que nos interesa es el del sector que han creado las grandes firmas de ropa, de accesorios y de complementos. En definitiva, la moda como expresión de la manera de vivir que tiene su mejor exponente en el vestuario. La fotografía de moda necesita también estar en constante renovación, buscando incesantemente cualquier tipo de innovación (Susperregui, 2000: 286), puesto que el hecho de mostrar las últimas tendencias le exige imágenes frescas y nuevas. Por tanto, frente a otros tipos, la fotografía de moda es más efímera al estar sujeta a los ciclos de la moda.

Situándonos en esta acepción de la moda, puede decirse que la fotografía de moda presenta las últimas tendencias y los nuevos diseños a través de la Prensa especializada (Susperregui, 2000: 285). Las ventajas que presenta la fotografía para la moda son numerosas, entre ellas, destacar que la imagen establece una comunicación inmediata, se recuerda mejor que las palabras y es un lenguaje universal (Burke, 2001). Además de su facilidad para su reproducción en masa.

La fotografía de moda publicita a la industria de la moda, es decir, forma parte de un proceso: pertenece a dicha industria. Está al servicio de unos objetivos comerciales que hace que se creen fotografías en las que todo es intencionado. Podemos decir que es un tipo de comunicación persuasiva, en la que se busca crear imágenes atrayentes destinadas a seducir al público (Santa-Cruz, 2005: 124). Este tipo de imágenes que inundan diariamente las vallas publicitarias, los blogs y revistas especializadas, necesitan tener un gran impacto ya que su vida es increíblemente corta. La moda cambia constantemente, se renueva cada temporada. Las nuevas tendencias invalidan las imágenes que se habían venido haciendo hasta ese momento. "La libertad a la hora de sacar el mayor partido a las posibilidades sugestivas y expresivas de los diseños, les permite utilizar distintos estilos, técnicas, plantear el trabajo en estudio o exterior, etc." (Martín, 2005: 115). Sin embargo, también implica, que la industria fotográfica deberá adaptarse con la misma rapidez que la moda y producir nuevas imágenes para dar sensación de constante novedad. Éstas se definen por su contemporaneidad: la inspiración y las ideas están en lo que sucede alrededor, en la sociedad del momento. De ahí que se diga que la fotografía de moda capta los gustos y la esencia de cada época. Así de categóricamente lo afirmaba la conocida directora de la edición estadounidense de Vogue, Anna Wintour, "una buena fotografía de moda, una buena producción de moda, cuenta tanto del momento en que se hizo como un titular del New York Times" (Brokes, 2006: s.p)

Sin embargo, la fotografía de moda no reproduce directamente la realidad, sino que se basa en puestas en escena; es decir, interpreta la realidad. Concibe escenarios artificiales y poco habituales, creando universos propicios para conseguir sus fines. Mediante la iluminación y la composición, nos sitúa en el reino de la fantasía. Por tanto, hay un distanciamiento entre la fotografía y la realidad. La realidad se 
transgrede para hacerla más sugerente. "Necesitamos la ficción de la fotografía de moda para poder representar como tal, a la tendencia de que trata la moda" (SantaCruz, 2005: 125). Se construye, por tanto, un mundo que sólo existe en las fotografías, creando mundos inventados, pero casi siempre con apariencia real.

\section{El surrealismo fotográfico}

Al igual que se puede hablar de pintura surrealista, también tenemos numerosos ejemplos de fotografía surrealista. De hecho, el medio técnico más apropiado para el surrealismo parecía ser la fotografía, ya que una pintura, por ejemplo, de Dalí, siempre es reconocida como una invención. Sin embargo, la fotografía, que por sus características intrínsecas obtiene una realidad observable y verificable, suponía el gran reto para adentrarse en otra realidad (Eguizábal, 2011: 148)

El surrealismo es un término inventado por el poeta Guillaume Apollinaire (1880-1918) según la definición del mismo que hizo André Bretón (1896-1966) en el primer manifiesto surrealista presentado en 1924.

Surrealismo: sustantivo, masculino. Automatismo psíquico puro, mediante el cual se intenta expresar verbalmente, por escrito o de cualquier otro modo, el funcionamiento real del pensamiento. Es un dictado del pensamiento, sin la intervención reguladora de la razón, ajeno a toda preocupación estética o moral. (...) El Surrealismo se basa en la creencia en la realidad superior de ciertas formas de asociación desdeñadas hasta la aparición del mismo, y en el libre ejercicio del pensamiento (Baudot, 2003: 4)

Ante la decepcionante experiencia de la Primera Guerra Mundial surge un movimiento que se evade de la realidad externa, mostrando su oposición a la irracionalidad, la destrucción y la animadversión que se había generado. El surrealismo se caracteriza por querer desvelar procesos de sentimiento irracional, por no mostrar la realidad exterior, como hasta entonces se había hecho. De alguna manera, las ideas y los sentimientos necesitaban salir de dentro de modo que, a la hora de crear sus obras, los artistas liberan al inconsciente de toda racionalidad permitiendo que la imaginación se deje llevar por sus deseos sin la intervención de la razón.

Los surrealistas tratan de plasmar el mundo del subconsciente, lo dictado por el pensamiento, expresado lejos del control y de los cánones estéticos. Se trata de crear una belleza contraria al concepto clásico de equilibrio, o a la idea de semejanza con la realidad. Entre las fuentes de inspiración del surrealismo se encuentra el mundo de los sueños, por su irracionalidad. De ahí la precisión en los detalles -igual que en nuestros 
sueños- y de ahí las imágenes llenas de misterio, sin ninguna lógica en la que aparecen objetos sin ninguna conexión entre sí.

El surrealismo fotográfico como tal, nace en los años veinte del siglo pasado. Si bien, es cierto que, a priori, fotografía y surrealismo son términos que podrían resultar contradictorios, los surrealistas supieron utilizar la fotografía como un instrumento de expresión y reflejo del inconsciente (Sougez, 2001:335). Para estos artistas la fotografía se convierte en un vehículo de trasgresión al permitirles realizar imágenes desligadas de los planteamientos estéticos tradicionales. El crítico alemán, Walter Benjamin, en su ensayo La obra de arte en la era de la reproducción mecánica ya "habla del inconsciente óptico y de la capacidad de la fotografía de abrir espacios que antes existían sólo en sueños" (Bright, 2005: 10)

Hasta ese momento, la fotografía se había usado como un medio que transcribía la realidad. Sin embargo, este nuevo grupo de fotógrafos no quería imitar la realidad, sino expresarse liberando los instintos y el inconsciente. Los fotógrafos se alejaron de la realidad mediante imágenes inéditas, desconocidas para el ojo humano. Ante el descontento con la cultura establecida se afanaron por encontrar una nueva visión del mundo y crear una nueva realidad.

Si bien es cierto que el surrealismo fotográfico tuvo su máximo auge tras la Primera Guerra Mundial, continuó en la obra de autores como Brassai, a través de sus fotografías de los signos en las paredes de las calles de París. En otros casos, pueden ser escenas preparadas buscando intencionadamente el tono surrealista, como las fotografías de Philippe Halsman sobre Dalí.

\subsection{El surrealismo encontrado}

La fotografía surrealista recurre principalmente a dos procedimientos diferenciados, el surrealismo encontrado y el técnico. El surrealismo encontrado, crea imágenes sin producir ninguna manipulación en la escena, sino como producto de un encuentro casual. Estas composiciones al azar, que despertaron el interés de los fotógrafos influidos por el surrealismo "habría que contemplarlas como una analogía al objet trouvé" (Tausk, 1978:70). Se crean así representaciones oníricas a través del objeto encontrado, combinando en una sola imagen elementos imposibles o poco probables, tal como hacían los pintores surrealistas.

La versión fotográfica del surrealismo consiste en buscar circunstancias extrañas, nuevas o fuera de contexto. Situaciones que se pueden dar en la realidad, pero que no son habituales: los fotógrafos surrealistas saldrán a la búsqueda encuentros fortuitos. Debido a su fidelidad documental, la fotografía se presentaba como el instrumento ideal para plasmar los objetos inconexos, convirtiéndose en testimonio de la existencia 
de ese encuentro casual, consiguiendo desligarse de la realidad debido a la incongruencia y la falta de sentido del contenido (Tausk, 1978:70).

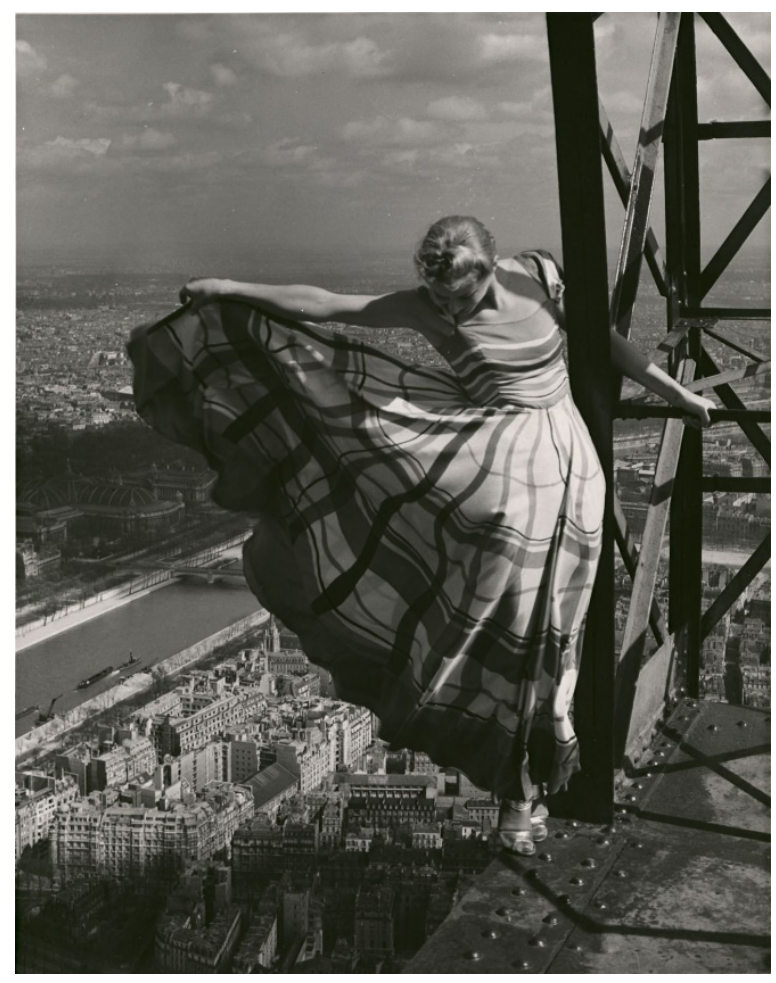

Erwin Blumenfeld. Vogue, Mayo 1939

Las imágenes surrealistas están llenas de visiones que plasman el mundo de los sueños, de la locura y las alucinaciones. La falta de lógica revela el carácter enigmático de los sueños. Mediante estas visiones reivindican una nueva belleza, "la belleza será convulsa o no será", escribía Bretón (Baudot, 2003: 16). Para los fotógrafos surrealistas la casualidad facilitará la creación de las escenas oníricas. La entrega al azar juega un papel muy importante, dejando un amplio margen creativo en esa búsqueda del hallazgo casual. De ahí que no haya una idea previa, ninguna reflexión ni intención premeditada. En ese sentido, imitan la conducta infantil, entregándose a la espontaneidad. También les caracteriza el interés por los detalles nimios pues la identificación de los objetos como tales no constituye en absoluto la razón de la fotografía. Crean así imágenes incongruentes, en las que muchas veces no se entiende lo que estamos viendo. La fotografía surrealista hace pensar e imaginar, busca la reacción del espectador, creando, incluso, cierto desasosiego en este.

Otra manera de conseguir imágenes nuevas será buscar ángulos de toma y perspectivas, como el punto de vista aéreo o la utilización de la vista en picado extremo, o distancias inusuales entre la cámara y el motivo. Al variar el punto de vista se cambia la apariencia de los temas y se crean imágenes visualmente más interesantes. Mediante estos ángulos y perspectivas buscan la visión ignota (no 
conocida, ni descubierta) en su afán de mostrar una visión novedosa y de romper con la imagen consagrada y las composiciones clásicas.

\subsection{El surrealismo técnico}

Desde los años veinte hasta la Segunda Guerra Mundial, la fotografía principalmente tomará dos caminos. Como ya afirmó en 1998 la profesora Casajús, por un lado, estuvo la experimentación subjetiva que quiso averiguar hasta dónde llegaban los límites del medio fotográfico y por otro lado se desarrolló la "Nueva Objetividad" (Casajús, 1998:118).

El surrealismo técnico, consiste en la manipulación de las imágenes, principalmente en el laboratorio para romper con la realidad y a su vez, liberar la imaginación del artista. Mediante las técnicas utilizadas para manipular, se consigue transmitir conceptos surrealistas como el automatismo psíquico y la libre asociación de ideas. "Los fotógrafos surrealistas en su intento de realizar imágenes que estuvieran al otro lado de la realidad y al mismo tiempo basadas en la reproducción de objetos reales, fueron aficionados a utilizar técnicas de laboratorio no usuales, retornando en su búsqueda al camino iniciado por algunos pioneros de la fotografía" (Casajús, 1998: 120). Los fotógrafos surrealistas recurren frecuentemente a técnicas puramente fotográficas como el fotomontaje, la solarización y el fotograma en su afán de experimentación con la luz, las sombras y las formas.

Los fotógrafos que se vieron influidos por el surrealismo practicaron de manera frecuente el fotomontaje. Bien es cierto que, técnicamente, el fotomontaje no es una novedad, pero ahora permitía la posibilidad de reproducir imágenes irracionales de manera casi simultánea. Era automatismo pictórico, la contrapartida visual de la escritura automática, de la literatura subconsciente que tanto apreciaron, en primer lugar, los dadaístas, y posteriormente los surrealistas. El fotomontaje era el perfecto complemento de la poesía del azar (Scharf, 1994:296). De manera sucinta, podemos decir que un fotomontaje es la fusión de dos fotografías en la que se mezclan distintos espacios y tiempos. Básicamente consiste en pegar fotografías y recortes, añadiendo, en algunos casos, tipografía, color y a veces, volviendo a fotografiar el resultado, creando así una nueva realidad. Está, por tanto, lleno de posibilidades y abierto a la fantasía, puede ser una mezcla de pintura, fotografía, recortes de periódicos, letras, etc. Como bien señala Raúl Eguizabal "Si se trata de buscar la yuxtaposición inesperada y sorprendente de cosas sin relación alguna (a la manera de la famosa frase de Lautréamont del paraguas y la máquina de coser) el fotomontaje es la manera idónea de expresar la irracionalidad y el sin sentido" (Eguizabal, 2011: 148) 
Mediante la técnica de la solarización, también conocida como efecto Sabatier, se obtiene una imagen con contornos perfectamente subrayados mediante líneas negras, de esta forma, el motivo resaltará aún más del fondo ya que queda silueteado.

Mediante la técnica del fotograma -tampoco nueva, aunque considerada más bien una versión moderna de los dibujos fotogénicos de William Henry Fox Talbot- se obtiene una fotografía sin cámara, por tanto, no interviene la óptica, sólo la luz. Las imágenes se crean reuniendo objetos sobre una hoja de papel sensibilizado que se exponen a la luz de la ampliadora y, a continuación, se revela normalmente. Mediante el fotograma se obtiene una copia única, los surrealistas se desligan así de la multiplicidad, característica intrínseca de la fotografía. Y también se desligan de la cámara, no se subordinan a ella, y del parecido hacia lo fotografiado, por tanto, consiguen desligarse de la analogía con la realidad.

\section{Fotografía de moda y el surrealismo}

Durante las primeras décadas del siglo XX se fueron estableciendo los cimientos de la fotografía de moda: poco a poco la figura del "fotógrafo de moda" se fue profesionalizando y el número de publicaciones periódicas especializadas en moda fue en aumento (Martín, 2005:116). No debemos olvidar que las revistas de moda estuvieron entre las primeras que hicieron un uso regular de la fotografía (Newhall, 2002:263). La Primera Guerra Mundial propició que Estados Unidos, con una floreciente economía en ese momento, cobrará gran auge en este campo. Entre los pioneros de la fotografía de moda figuran Adolf de Meyer (1868-1946) y Edward Steichen (1879-1973), ambos contratados por Condé Nast, propietario de varias revistas, entre ellas Vogue y Vanity Fair. La contratación de fotógrafos altamente cualificados para integrarse en los equipos artísticos de las revistas especializadas supuso el inicio de la fotografía de moda tal y como hoy la conocemos" (Martín, 2005: 117)

En el periodo de entreguerras surge una segunda generación de fotógrafos, como el inglés Cecil Beaton (1904-1980), caracterizado por poner el énfasis "en la escenografía, a menudo complicada, que ha sido construida especialmente para la ocasión" (Newhall: 2002,266) o el húngaro Martin Munkacsi (1896-1963), quien traslada toda su experiencia del reportaje deportivo a la fotografía de moda, o George HoyningenHuené (1900-1968), que destacó por la elegancia y el clasicismo de sus imágenes. Como fotógrafos también sobresalieron Horst P. Horst (1906-1999), formado como arquitecto, con una larga trayectoria como fotógrafo de moda, manteniéndose siempre fiel a Vogue y quien introduce en sus imágenes escenarios y unas poses originales del mundo grecorromano, que "junto con su peculiar sentido de la belleza 
nos resultan a menudo surrealistas" (Caravias:2005,23). Destaca también Man Ray (1890-1976), uno de los primeros representantes de la corriente surrealista. Ambos autores simbolizan el triunfo de la creatividad, la visión individual y la búsqueda de la innovación, ejemplificando la fusión entre el arte y la moda.

Fue un momento en el que la fotografía de moda todavía no había alcanzado su madurez como género y estaba abierta a todo tipo de estilos, acogiendo a fotógrafos diferentes, la mayoría de ellos con formación artística. Durante estos años, la Prensa femenina americana jugó un papel clave. Destacaron especialmente Vogue y Harper's Bazaar. En aras de un mayor prestigio, los editores apostaron por grandes colaboradores, tanto escritores como ilustradores y fotógrafos. Coincidió, además, con la llegada desde 1930 de grandes directores artísticos como Alexey Brodovitch o Alexander Liberman (Martín:2005,117). Así mismo, en estos años, las vanguardias artísticas también se hicieron presentes en las publicaciones de moda, que acogieron las tendencias de la época, construyendo una relación muy estrecha con los artistas.

La Segunda Guerra Mundial y sus restricciones afectaron, entre otras tantas cosas, a la moda y a la fotografía. Con la ocupación alemana, París se quedó aislada y tanto Gran Bretaña como EEUU empezaron a crear sus propias tendencias. Estados Unidos, por su parte, marcará una línea de ropa de uso cotidiano. "Durante el periodo de entreguerras, gracias a una industria competitiva, bien gestionada, innovadora en cuanto a las técnicas de marketing, el ready-to-wear experimenta un desarrollo importante" (Baudot: 2008, 122). El aislamiento de París permite a Estados Unidos sacar provecho a su creatividad local.

Los años cuarenta estuvieron marcados por la austeridad que imprimió la Segunda Guerra Mundial, teniéndose que adaptar la moda a esta nueva realidad: los modelos se caracterizarán por su sencillez y funcionalidad. Las restricciones acarreadas por la Segunda Guerra Mundial (1939-1945) provocaron la escasez de materiales textiles y la exigüidad de materiales y medios fotográficos. La moda, por tanto, tuvo que enfrentarse a esta nueva situación. Por tanto, la fotografía se tuvo que esforzar para atraer al público. Será por esos años cuando llegue a Estados Unidos Erwin Blumenfeld, quien seguirá la tendencia experimental.

En los años cincuenta, con la guerra terminada, vuelve la prosperidad y el optimismo, se reactiva el consumo, renaciendo el deseo de vender sueños y glamour. Las dos grandes revistas rivales americanas, Vogue y Harper's Bazaar, darán a sus fotógrafos total libertad. Esta libertad creativa supondrá que la fotografía de moda alcance su madurez. En estos años destacaron dos grandes fotógrafos, Irving Penn (1917-2009) y Richard Avedon (1923-2004). Tanto Penn como Avedon son dos figuras claves en la evolución de la fotografía de moda, ambos plantearon una vuelta a lo puramente fotográfico y rompieron con la interacción entre moda y arte de los fotógrafos que les precedieron (Martín,2005:118). Los dos acabaron con las puestas en escena 
recargadas, recurriendo a decorados sencillos, limitando el número de objetos y de luces que aparecían en sus imágenes.

En los años sesenta y primeros setenta se impone la contracultura, en una clara idea rupturista con los esquemas de los marcos de autoridad (Marcuse:1968): las dos palabras que mejor definen estas décadas son juventud y música. En el campo de la moda, los profundos cambios sociales de estos años harán que sea uno de los periodos más decisivos del siglo. La moda se democratiza y se impone el prêt-à-porter. "A partir de ese momento, se termina la tendencia unívoca y la moda única, y en su lugar surge un mosaico de propuestas indisociables de las que influyen en los demás aspectos de la vida cotidiana" (Baudot: 2008, 186). La moda regresa a Europa, y Londres, de manera efímera, se convierte en centro de la música y las tendencias con una Mary Quant que lanza la minifalda, impulsando una nueva era. En los años setenta, París también vuelve a ser la meca de la moda. Tanto los consumidores como los artífices de la moda son jóvenes, la fotografía en color domina ya las revistas de moda. Entre los padres de la fotografía moderna cabe citar a Helmut Newton (1920-2004) y Guy Bourdin (1924-1992). Este último se convirtió en icono para la siguiente generación de jóvenes fotógrafos por el uso de los colores vivos y por sus imágenes cargadas de sensualidad.

Desde sus inicios, el surrealismo fue utilizado por los fotógrafos de moda como Cecil Beaton, Man Ray o Horst P. Horst, e incluso por la fotografía publicitaria. Como afirma la profesora Casajús, en su trabajo de referencia sobre fotografía de moda, "Surrealismo y la fotografía, se encontraron prácticamente desde su nacimiento. Hecho bastante lógico, porque el grupo surrealista había manifestado desde su fundación oficial en 1924, un acusado afán de experimentación que le condujo inevitablemente a la utilización de todo tipo de materiales y texturas, a la aceptación del elemento mecánico y a la inclusión en sus filas de los fotógrafos y sus imágenes" (Casajús, 1993:338). Revistas como Vogue o Harper's Bazaar van a ayudar a popularizar el surrealismo. Este pasó a significar lo moderno, reemplazando el idealismo neoclásico practicado por otros fotógrafos como George Hoyningen-Huené, además de ser muy apropiado porque llamaba mucho la atención.

El surrealismo encaja muy bien con la fotografía de moda ya que muchas de sus características van a poder ser aplicadas por esta disciplina. Para empezar, la fotografía de moda, lo mismo que cualquier obra surrealista, realiza imágenes que se alejan de la realidad para crear sueños e ilusiones en el espectador. Así mismo, la creatividad, tanto en moda como en el surrealismo, juega un papel fundamental, no debe olvidarse que el margen creativo en fotografía de moda es mayor que en otros géneros fotográficos. Tanto la moda, como las revistas especializadas y la publicidad de las marcas de moda permiten y exigen al fotógrafo tener un alto grado de creatividad. Por otro lado, a los surrealistas, como ya se apuntó, les mueve el deseo de diferenciarse, 
de sobresalir del resto. Y lo mismo sucede en la moda, hay una necesidad de crear imágenes originales y de sorprender al lector. Cada fotografía tiene que ser algo nuevo e ingenioso. Todo esto conlleva a una innovación constante, el fotógrafo debe aspirar a hacer un trabajo que le haga destacar y también debe desarrollar un estilo propio que le distinga.

\subsection{Erwin Blumenfeld}

Con el afán de experimentar con diferentes métodos de crear imágenes, llegó a Estados Unidos el fotógrafo, de origen alemán, Erwin Blumenfeld (1897-1969). Sus creaciones son una búsqueda incesante de renovación y creatividad, en las que el vestido resulta una mera justificación ya que le otorga más importancia a la proyección de su propia fantasía. La manipulación fotográfica, hacía que sus imágenes -por su creatividad, originalidad e innovación- puedan llegar a ser consideradas verdaderas obras de arte. En ellas subordina la composición, la técnica fotográfica y las modelos a sus propias ideas, sin someterse a los requerimientos formales de la fotografía.

Sus imágenes se caracterizan por el uso de una gran variedad de técnicas de laboratorio, por ejemplo, influenciado por Man Ray, al que admiraba, aplica la técnica de la solarización a los desnudos, otra técnica recurrente es la superposición de imágenes (Casajús:246). También crea imágenes con mucho grano, o juega a crear sombras en la piel interponiendo una rejilla entre el foco de luz y la modelo. Creando así imágenes ambiguas en las que busca interpelar al espectador.

En el año 1939 realiza para la edición francesa de Vogue una de sus fotografías más conocidas y una de las más imitadas "Lisa Fonssagrives on the Eiffel Tower, París 1939" La modelo luce un vestido de Lucien Lelong desde lo alto de la torre Eiffel y a sus pies se aprecia París. Esta es una de las escasas imágenes en las que Blumenfeld utiliza como fondo un escenario real y de las pocas que hace fuera de un estudio. "La imagen fue memorable por la sensación de sorpresa y peligro que daba" (Angeletti\&Oliva, 2011:160). Esta imagen responde a la versión fotográfica del surrealismo encontrado, que busca circunstancias extrañas, nuevas o fuera de contexto. Situaciones que se podrían dar en la realidad, pero que no son nada habituales.

En 1941, dado su origen judío, abandona Europa y se instala en Nueva York con su familia, obteniendo gran éxito como fotógrafo de moda y como artista. Comienza trabajando para Harper's Bazaar, después en Vogue América y otras publicaciones como Life o Cosmopolitan. En Estados Unidos, la fama no tardó en llegarle y, hacia finales de los 40, Blumenfeld, era el fotógrafo mejor pagado, llegando a ser uno de los más importantes de su generación. Hizo infinidad de portadas para las revistas y fue uno de los primeros en experimentar con la fotografía en color, que estaba todavía en sus inicios. Será en Nueva York donde comience la transición de imágenes en blanco y 
negro a fotografía en color pues así se lo pedían las publicaciones para las que trabaja. Esto, a su vez, le llevaría a replantearse la iluminación y la composición de sus imágenes. En este contexto Blumenfeld llega a desarrollar su propio lenguaje del color, con un gran número de tonos.

Blumenfeld no busca representar la realidad, por ello, en repetidas ocasiones sitúa a las modelos detrás de cristales, creando contornos desdibujados, o coloca espejos estriados delante del objetivo en aras de crear nuevos efectos y un cierto desconcierto. Incluso utiliza filtros de colores para dar la sensación de ensueño a las escenas. Así mismo, las composiciones utilizando espejos son reiteradas. El espejo proporciona una doble visión, mostrando una parte del cuerpo, como el rostro o el torso de frente, y su perfil, permitiendo la repetición de elementos. "Juegos de espejos o simulacros enigmáticos... eludiendo las convenciones y la objetividad de la cámara oscura para así enriquecerla con hallazgos, con una poética y con símbolos surreales" (Baudot:2003,17)

En muchas de sus imágenes las mujeres aparecen con los ojos cerrados como si estuvieran dormidas o ausentes. En este aspecto también se observa la influencia surrealista de Blumenfeld, ya que como se ha mencionado, el surrealismo tiende a representar el inconsciente, a poner el acento en lo irracional de los sueños. Así mismo, sus modelos son "mujeres misteriosas y simbólicas. Está ausente la personalidad propia de cada una de ellas, son la mujer en general” (Casajús: 1993,247)

Aunque realiza una gran parte de su producción fotográfica de moda tras su llegada a Estados Unidos, su estilo estará influenciado por la fotografía europea de los años 20 y 30, así como por los movimientos dadaístas y surrealistas, con los que tuvo contacto tras vivir en Berlín, Ámsterdam y París. 


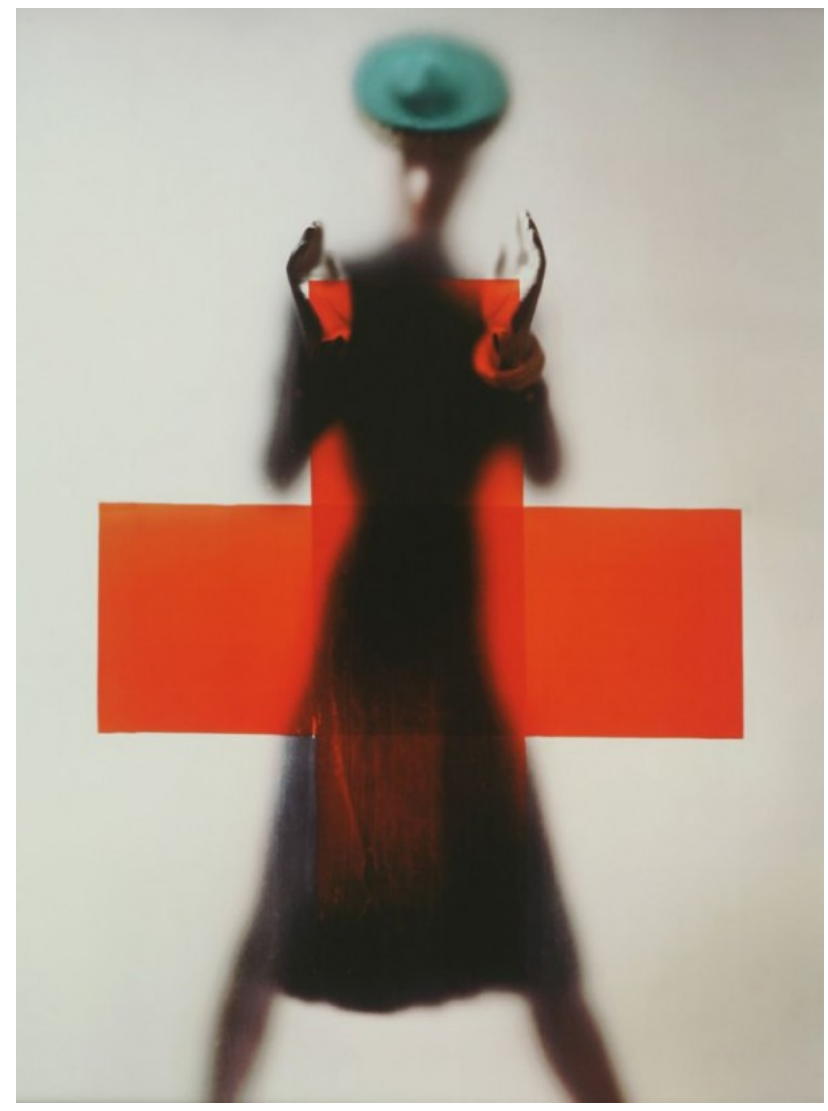

E. Blumenfeld, Red cross, NewYork, 1945

A modo de conclusión podemos señalar que Blumenfeld realiza un tipo de composiciones novedosas en los que muestra la ropa, pero sin reproducirla tal cual, dando más importancia a la búsqueda de lo insólito, al igual que los surrealistas. Tomando el elemento sorpresa de sus experimentos de la etapa dadaísta. Así mismo, el azar interviene en sus imágenes, tanto en la toma, como en la manipulación en el laboratorio, algo que no abandonará nunca. Su estilo, alejado de los convencionalismos de la fotografía, se caracteriza por osados efectos ópticos y por un preciso control de la luz y de las técnicas de laboratorio.

\subsection{Guy Bourdin (1928-1992)}

En la década de los sesenta y setenta se impone el prêt-à-porter, lo que viene a significar la democratización de la moda. La moda, así como la música, pasarán a estar dominadas por la juventud, tanto los consumidores como los artífices son principalmente jóvenes. En este contexto surge una nueva generación de jóvenes fotógrafos que rompieron con el imperativo de la generación anterior de belleza y elegancia. Entre ellos, Guy Bourdin, considerado uno de los padres de la fotografía de moda contemporánea. Personaje singular, con una vida envuelta en un halo de misterio: vanguardista, rompedor e innovador, creador de escenas que contienen 
complejas narraciones, a la vez que provocativas. Sus imágenes son una mezcla de cierta violencia implícita, temas tabúes relacionados con el sexo y un ácido sentido del humor. Los paisajes solitarios se convirtieron en un sello de su obra, así como las atmósferas llenas de suspense y los escenarios criminales.

A este francés su fama le llegó por sus anuncios para el diseñador de zapatos de alta costura, Roland Jourdan, con el que estuvo trabajando durante más de 15 años, y por sus imágenes para Vogue París, publicación para la que trabajó durante más de treinta años, desde 1955 a 1987.

La principal influencia que recibió Bourdin durante su formación en París en los años 20 y 30, fue la del surrealismo. Admiraba a Man Ray y buscó su amistad, llegando a convertirse en su protegido. En 1954 comienza a trabajar para Vogue, por aquellos años la fotografía de moda todavía seguía marcada por el convencionalismo funcional derivado del conflicto armado, con mucho margen hacia la idealización. Guy Bourdin fue capaz de romper con esto, introduciendo fragmentos de cotidianidad, mostrando a los modelos en situaciones reales, a veces, absurdas o disparatadas. De especial importancia fue el apoyo que recibió en Vogue por parte de Francine Crecent, quien desde que en 1967 fue nombrada redactora-jefe, tratará de incluir el mayor número de imágenes de Bourdin en la revista. Por aquellos años Vogue Francia concedía a sus fotógrafos una libertad sin precedentes.

Creador de un estilo muy personal, mediante composiciones transgresoras, utilizando una iluminación teatral y unos colores vivos y saturados, ya que en estos años el color se había impuesto por completo en las revistas de moda. Si bien no fue el primero en desmitificar el objeto de moda, podemos interpretarlo como uno de los más radicales en su aproximación.

En su fase de madurez será consciente de que "mediante un encuadre y una composición sorprendentes podía crear escenas voyeuristas cargadas del suspense propio de las películas de serie B" (Gingeras, 2006: s.p.). Algunos críticos defienden que Guy Bourdin fue el primer narrador explícito en la fotografía de moda.

En sus imágenes se puede apreciar la influencia surrealista, no sólo de Man Ray, también de pintores como Francis Bacon o Magritte. En sus imágenes inserta accesorios y elementos fetichistas, o utiliza el maniquí, "uno de los elementos recurrentes del surrealismo (...) que simboliza ante todo una ausencia" (Baudot, 2003:7). Busca la provocación y crea, además, escenas con mensajes difíciles de descifrar, moviéndose en el mundo de lo absurdo y rompiendo con la fotografía comercial convencional.

Así mismo, también se puede apreciar la influencia del surrealismo en su actitud ante el desnudo, ya que en su obra es recurrente la utilización de modelos parcialmente 
desnudas, con poses muy exageradas y complicadas, jugando con el contraste entre las partes desnudas y las cubiertas, resaltando así el efecto erótico:

Dentro del espíritu del objet trouvé se valoraba, ante todo, la conjunción poética de curvas y formas del cuerpo femenino, que podía ser variado por la elección de diferentes puntos de colocación y movimientos muy limitados. (Tausk, 1978:72).

Plasmar sus surrealistas visiones en la era previa al retoque digital requería elaborados decorados, trucos y modelos dispuestas a soportar todo tipo de incomodidades. Tenía fama de ser muy exigente y proliferan historias sobre sus estrambóticas demandas, que incluyen tratar de teñir el mar o cubrir de pegamento a una modelo.

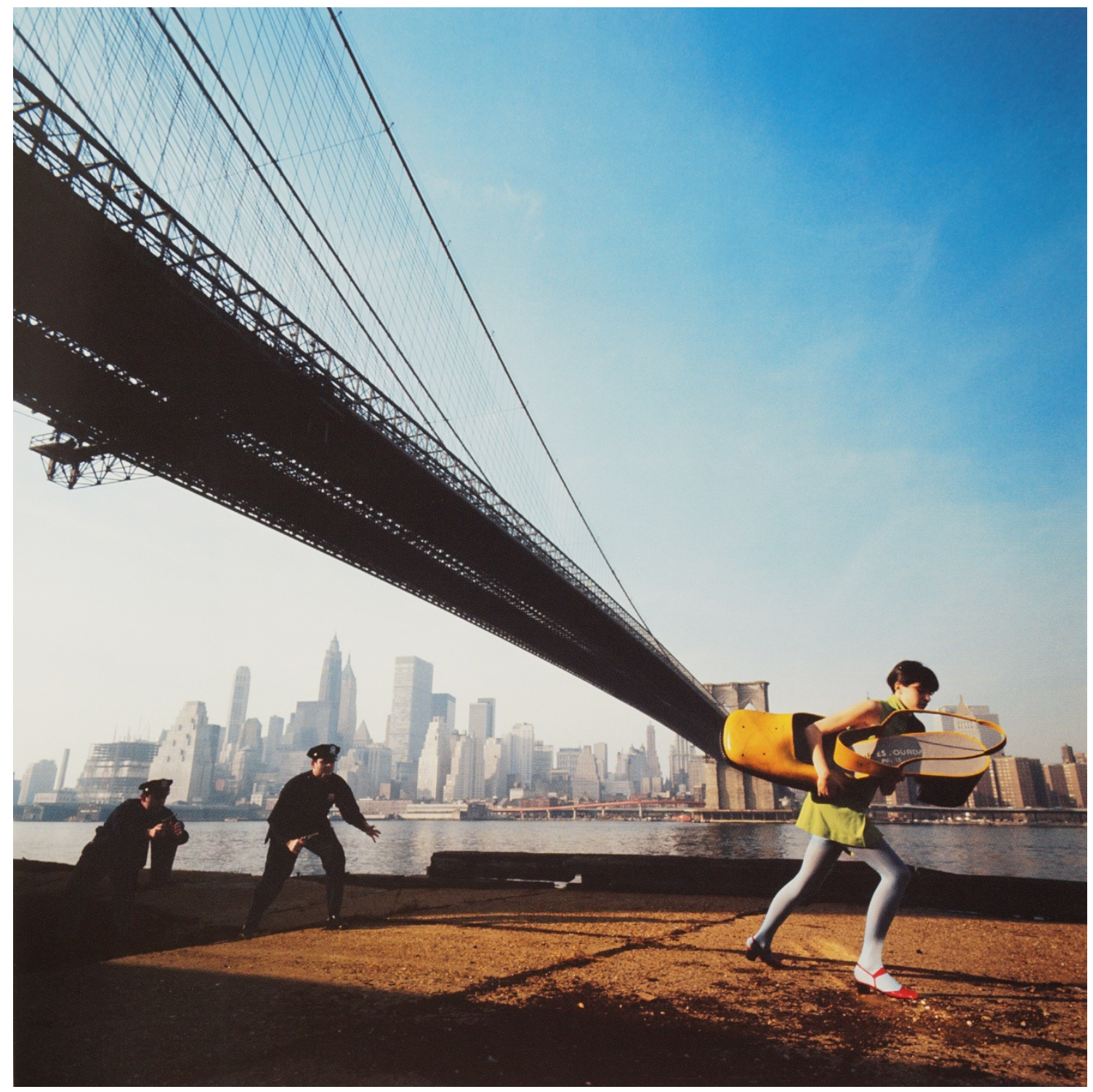

G-Bourdin-Anuncio para Charles Jourdan, primavera 1968

Sus imágenes, muchas de ellas un alto contenido sexual, otras de violencia latente o incluso con claras alusiones a asesinatos provocaron gran polémica, "desde la mirada 
feminista se censura esa visión glamurizada de la mujer en escenas que evocan o sugieren violencia, muerte, prácticas sadomasoquistas, etc." (Gámez, 2017: s.p)

Bordin deja de trabajar a finales de los ochenta y fallece en 1991, a los sesenta y dos años. Sin embargo, el impacto de sus imágenes puede percibirse en algunos fotógrafos actuales, como Steven Meisel. Porque Guy Bordin revolucionó el género de la fotografía de moda: sus imágenes reflejan los cambios que se estaban viviendo en la sociedad y en la moda de aquellos años dominados por la juventud. "A partir de estos años los conceptos predominantes pasaron a ser otros: las modelos transmitieron sexualidad" (Angeletti\&Oliva, 2011: 200)

Al igual que en los surrealistas, la importancia concedida al proceso creativo, el atrevimiento, la ambigüedad y la provocación fueron una constante de su obra. Creador de un lenguaje propio -mediante sugerentes composiciones y atención a los detalles- recurrió frecuentemente a escenas seductoras o entornos desconcertantes, narrando historias más que exponiendo productos de moda. La influencia surrealista la encontramos también en sus escenas sobrecargadas y recurso al preciosismo y a la descontextualización (las piernas andando solas son recurrentes en su obra). Guy Bordin, al igual que hacían los surrealistas buscaba la provocación mediante asociaciones libres y rupturas subversivas.

\section{Conclusiones}

La interacción entre la fotografía de moda y el arte ha sido continua: desde sus inicios la fotografía de moda estuvo unida a los movimientos artísticos, entre otras cosas por la formación artística de los primeros fotógrafos de moda.

La fotografía de moda se distingue por combinar el elemento comercial y el artístico. Una fotografía de moda surge de un encargo, sin embargo, dado su fuerte contenido creativo, puede llegar a tener valor artístico

El surrealismo y la fotografía de moda se distinguen por su modernidad estética. Así mismo, los surrealistas van a usar la fotografía no como un elemento que imita, sino como un elemento que expresa. Y lo más importante en una fotografía de moda es que sea efectiva, es decir, que comunique.

Tanto el surrealismo como la fotografía de moda se basan en el alejamiento de la realidad. Aunque los fines distintos: el surrealismo busca alejarse de la realidad ante el descontento con la cultura establecida mientras que la fotografía de moda -que mantiene una ambigüedad entre ficción y realidad- intenta crear una realidad más estimulante e idealizada. 
El surrealismo presenta una serie de elementos que la fotografía de moda ha sabido adaptar, como, por ejemplo, el alto grado de creatividad, el hecho de que la imaginación juegue un papel de suma importancia, y el deseo de crear un sello personal en la búsqueda constante del elemento sorpresa. No debe olvidarse que las imágenes de moda necesitan ser impactantes debido a la fuerte competencia y lo efímero de su utilidad.

A través de los ejemplos presentados hemos podido certificar que el surrealismo ha sido fuente de inspiración para la moda, no sólo durante el momento de auge del surrealismo en los años 20 y 30, sino también en los fotógrafos de moda que entre los 40 y 70 , recurrieron a elementos del surrealismo técnico y encontrado.

A pesar de que el elemento comercial está presente, la fotografía de moda ha servido como vehículo de expresión personal y de subversión de los dos fotógrafos estudiados: Erwin Blumenfeld y Guy Bourdin.

Tanto Blumenfeld como Bourdin contribuyeron de forma significativa a la fotografía de moda, eludiendo la convención y la objetividad de la cámara, y creando imágenes inesperadas. Así mismo, en consonancia con el surrealismo y con el objeto de la fotografía de moda, utilizan a la mujer como elemento primordial dentro de su obra. Podemos concluir que en Bourdin, la influencia del surrealismo es más acentuada, sobre todo en lo que se refiere al contenido de sus imágenes ya que utiliza un mayor número de motivos de carácter onírico, incluso burlesco, recurriendo con frecuencia al cuerpo desnudo y a fotografías extraordinariamente drásticas en las que impera un clima de misterio.

\section{Referencias bibliográficas}

ANGELETTI, N \& OLIVA, A. (2011): In Vogue. Barcelona: Editorial Sol90 media.

BAUDOT, F. (2003): Moda y surrealismo. Madrid: Kliczkowski Publisher.

- (2008): La moda del siglo XX. Barcelona: Gustavo Gili.

BAILEY, G. (2011) Harper's Bazaar Greatest Hits: a decade of style. Nueva York: Abrams

BRETON, A. \& EDUARD, P. (2015) Diccionario abreviado del surrealismo. Madrid: Siruela.

BRIGHT, S. (2005): Fotografía hoy. San Sebastián: Editorial Nerea. 
BROCKES, E (2006): “La temible Anna Wintour" en El País Semanal, 8 de octubre de 2006. Disponible en Internet (8-02-2018): https://elpais.com/diario/2006/10/08/eps/1160288814_850215.html

BURKE, P. (2001): Visto no visto. El uso de la imagen como documento histórico. Barcelona: Crítica.

CARABIAS, M (2005): “Fotografía, modas y modelos". En Mujeres modelos, mujeres de moda 1850 -1940. Madrid: Ediciones Aldeasa.

CASAJÚS, C. (1993): Historia de la fotografía de moda. (Aproximación estética a unas nuevas imágenes). Tomo I. Tesis Doctoral. Universidad Complutense de Madrid.

- (1998): Manual de arte y fotografía. Madrid: Editorial Universitas.

DEVLIN, P. (1979): Vogue Book of Fashion Photography 1919-1979. Introduction by Alexander Liberman. London: Thames and Hudson.

DUCROS, F. (1998): "The dream of beauty. Fashion and fantasy". En A new history of photography. Editor Michel Frizot. Londrés: Kóneman.

EGUIZÁBAL, R. (2011): Fotografía publicitaria. Madrid: Cátedra. Colección Signo e Imagen.

FIGUERAS, J. (1997): La moda sus secretos y su poder. Madrid: Albacore.

GÁMEZ, C: (2017): “Guy Bourdin: ¿revolucionario de la fotografía de moda o el primer sádico de la imagen femenina?" en S Moda, 25 de julio de 2017. Disponible en Internet (14-04-2018), https://smoda.elpais.com/moda/guy-bourdin-exposicionchloe/

GARNER, P. et all (2009): Avedon Fashion 1944- 2000. Barcelona: Blume.

GARRIDO, M. (2012): Revistas femeninas de alta gama. Crónica de un desdén. Salamanca: Comunicación social ediciones y publicaciones.

GINGERAS, A. (2006): Guy Bourdin. London: Phaidon Press Limited.

HORST (2001): Horst Portraits, 60 Years of Style. London: National Portrait Gallery.

INCORVAIA, M.S. (2016): "La fotografía en la moda. Entre la seducción y el encanto" en Centro de Estudios en Diseño y Comunicación, cuaderno 57, pp 27-38. Disponible en Internet (15-01-2018): http://www.scielo.org.ar/scielo.php?script=sci_arttext\&pid=S185335232016000200003.

MARCUSE, H. (1968): El hombre unidimensional. Barcelona: Seix Barral. 
MARTIN, J-H. (1987): Man Ray Photographs. London: Thames and Hudson.

MARTÍN, C (2005): "La fotografía de moda como medio específico para la difusión de estilos y tendencias en el periodo 1920-1950". VI Congreso de Moda. Universidad de Navarra. pp 115-122.

METAYER, M. (2004): Erwin Blumenfeld. London: Phaidon Press Limited.

NEWHALL, B. (2002): Historia de la fotografía. Barcelona: Gustavo Gili.

PEREZ, M. (2016): “Asociaciones entre el arte y la moda en el siglo XX" en Centro de Estudios en Diseño y Comunicación, Cuaderno 57, pp.15-25. Disponible en Internet

(15-01-2018):

http://fido.palermo.edu/servicios_dyc/publicacionesdc/vista/detalle_publicacion .php?id_libro=555

SANTA-CRUZ, J (2005): "Una mirada filosófica a la fotografía de moda". VI Congreso de Moda. Universidad de Navarra, pp 123-128.

SCHARF, A (1994): Arte y fotografía. Madrid: Alianza Editorial.

STERN Fotografie (2011): Erwin Blumenfeld, portfolio oㅜ 65. Hamburgo.

SOUGEZ, M.L (2011): Historia General de la Fotografía. Madrid: Manuales Arte Cátedra.

SUSPERREGUI, J. M. (2000): Fundamentos de la fotografía. Bilbao: Universidad del País Vasco.

TAUSK, P. (1978): Historia de la Fotografía en el siglo XX. De la fotografía artística al periodismo gráfico. Barcelona: Gustavo Gili.

TORRES, R (2007): "Revistas de moda y belleza. el contenido al servicio de la forma". En Ámbitos no 16, pp. 213-225.

VELASCO, A.M. y REGUERO, I. (2016): La Historia a través de los Máss Media. Madrid: Vincent Gabrielle.

VV.AA. (2011): Fotografía de moda. Firenze: Scala group.

VV.AA. (2006): Horst. Platinum. Publisher Jefferies Cowan.

VV.AA. (2011): Moda. Una historia desde el siglo XVIII al siglo XX. La colección del Instituto de la Indumentaria de Kioto. Tomos I y II. Colonia: Ed. Taschen. 